\title{
Üniversite Öğrencilerinin İletişim Becerileri, Problem Çözme Becerileri Ve Bağlanma Stilleri İlişkisi ${ }^{1}$
}

\author{
DOI: $10.26466 /$ opus.622867
}

\author{
* \\ İknur Ezgi Koser*- Yaşar Barut ** \\ * Doktora Öğrencisi, Ondokuz Mayıs Ünivesitesi Eğitim Bilimleri Enstitüsü, Samsun/ Türkiye \\ E-Posta: ilknurezgikoser@outlook.com \\ ORCID: 0000-0002-2169-0915 \\ ** Dr. Öğr. Üyesi, Ondokuz Mayıs Üniversitesi, Samsun/ Türkiye \\ E-Posta: ybarut@omu.edu.tr \\ ORCID: $\underline{0000-0002-5027-2536}$
}

\section{Öz}

$B u$ çalışmada üniversite öğrencilerinin iletişim becerilerinin, problem çözme becerileri ve bağlanma stillerinin incelenmesi amactyla hazırlanmıştır. Araştırma Giresun (bir devlet) Üniversitesi'nde öğrenim görmekte olan basit seçkisiz örnekleme yöntemiyle belirlenmiş 300 lisans öğrencisinin katılımıyla gerçekleştirilmiştir. Araştırmada veri toplama aracı olarak kişisel bilgi formu, İletişim Becerilerini Değerlendirme Ölçeği (İBDÖ), Problem Çözme Envanteri, İlişki Ölçekleri Anketi kullanılmıştır. Araştırma sonucunda iletişim becerileri ile problem çözme becerileri arasında anlamlı bir ilişki bulunmuş̧tur. İletişim becerileri ile bağlanma stillerinin alt boyutunda yer alan korkulu ve saplantılı bağlanma stilleri ile aralarında negatif yönde anlamlı bir ilişki bulunmuştur. Problem çözme becerileri ile bağlanma stillerinin alt boyutunda yer alan güvenli veya kayıtsı bağlanma stili arasında anlamlı bir ilişki bulunmuştur. Cinsiyet ile bağlanma stilleri arasında bağlanma stilinin alt boyutlarında yer alan güvenli ve korkulu bağlanma stilleri arasında anlamlı bir ilişki bulunmuştur. Güvenli bağlanma stili erkek öğrencilerde daha yüksek iken korkulu bağlanma stili kadın öğrencilerde daha yüksek bulunmuştur. Üniversite öğrencilerinin yaşlarıyla iletişim becerileri arasında anlamlı bir iliş̧i bulunmuştur. 18-20 yaş grubuna göre 26 yaş ve üzeri yaş grubunun iletişim becerileri puanlarının daha yüksek olduğu saptanmıştır. Yaş ile bağlanma stilleri arasındaki ilişkiye bakıldığında yaş ile bağlanma stillerinin alt boyutunda yer alan kayıtsız bağlanma stiliyle arasında anlamlı bir ilişki bulunmuştur. Öğrencilerin yaşları arttıkça kayıtsız bağlanma stilleri de artmıştır.

Anahtar Kelimeler: İletişim becerileri, Problem çözme becerileri, Bağlanma stilleri,

\footnotetext{
${ }^{1}$ Bu makale, Illknur Ezgi Koser tarafından Dr. Öğr. Üyesi Yaşar Barut yönetiminde hazırlanarak Ondokuz Mayıs Üniversitesi Eğitim Bilimleri Enstitüsünde 29.04.2019 tarihinde kabul edilmiş olan yüksek lisans tezinden türetilmiştir
} 


\title{
Study Of Communication Skills, Problem Solving Skills And Involvement Styles On University Student
}

\begin{abstract}
This study was prepared to investigate communication skills, problem solving skills and involvement styles on university students. The research was actualized with participation of sampling was defined with simple random 300 undergraduate students who have been studying at Giresun University. On the research, personal information form as data collection tool, Communication Skills Assessment Scales, Problem Solving Inventory, Correlation Scales Survey. As a result of research, a significant correlation has obtained between communication skills and problem solving skills. A negative significant correlation has obtained with apprehensive and obsessive involvement styles which exist on lower dimension of communication skills and involvement styles. A significant correlation has obtained with safe and apathetic involvement style which exist on lower dimension of problem solving skills and involvement styles. A significant correlation has obtained between safe and apprehensive involvement styles which exist on lower dimensions between involvement styles with gender. Apprehensive involvement style has detected in higher levels for female students whereas safe involvement style has detected in higher level for male students. When the correlation between communication skills with ages has observed, a significant correlation has obtained between ages and communication skills. It has determined that communication skills points of aged 26 years older are higher than aged group of 18 20 years. When the correlation between ages and involvement styles has observed, a significant correlation has obtained with apathetic involvement style which exists on lower dimension of involvement styles. Apathetic involvement styles of students have also increased while their ages were increasing.
\end{abstract}

Keywords: Communication skill, Problem solving skill, Attachment styles 


\section{Giriş}

İnsan doğduğu andan itibaren hatta anne karnına düştüğü andan itibaren sosyal bir varlık olarak toplumsal yapının bir parçasıdır. İnsanın yaratılışı gereği toplumsal yaşama uygun bir halde dünyaya gelmiştir (Akkaya, 2018). İnsanla birlikte iletişim başlamıştır (Işık, 2012). İnsanın varoluşundan bu yana vazgeçilmez bir unsur iletişimdir. İnsanlar toplum haline iletişim sayesinde gelmişlerdir (Doğan, 1998). Bireyler bu toplumsal yaşama ne derecede başarılı bir uyum gösterirlerse yaşam doyumu ve kalitesi de o denli artacaktır (Akkaya, 2018). Diğer bireylerle geçirmiş olduğumuz etkileşimlerimiz, bağlarımız, ilişkilerimiz psikolojik ve zihinsel sağlığımız için belirleyicidir (Hartley, 2014). Bu süreçte bireye yardımcı olan becerilerden bir tanesi iletişim becerileridir. Öncelikle iyi bir iletişim becerisi iyi bir anlaşma demektir. Birey kendini ne kadar iyi bir şekilde ifade ederse ve ne kadar etkili bir iletişim becerisi kurarsa karşısındaki birey veya bireylerde onu daha iyi bir şekilde anlayacak hem de o karşısındakileri daha iyi anlayacak böylece sağlıklı ilişkiler kurulmuş olacaktır (Akkaya, 2018).

Hem bireysel yaşamında hem de toplumsal bir varlık olmasının gerektirdikleriyle birey yaşamı boyunca çeşitli sorunlarla karşı karşıya kalmaktadır (Güçlü, 2003). Değişen ve gelişen toplumsal yapı, teknoloji, siyasi ve sosyal yaşam, ekonomik krizler bireylerin karşı karşıya kaldıkları problemli durumlardan bazılarıdır (Taşçı, 2005). Birey bu karşı karşıya kaldığı bu sorunlarını etkili bir şekilde çözerek bireysel başarısını, birey olma ve çevreyle baş etme gücünü gösterir. Bireyin birey olmasını, çevresini istediği yönde değiştirmesini, karşılaştığı güçlükleri aşmasını sağlayan, yaşamından doyum almasını, kendini yeterli ve başarılı hissedebilmesi, huzurlu, mutlu, sağlıklı bir yaşam sürdürebilmesi için gerekli olan temel becerilerden biri de problem çözme becerisidir (Güçlü, 2003). Problem çözme becerisi, bireylerin ait olduğu gruba ve yaşadığ çevreye aktif bir şekilde uyum sağlamasına yardımcı olur (Mertoğlu ve Öztuna, 2004). Bireyin problem çözme becerisi ne kadar gelişmiş ise çevreyi algilaması ve davranışları o kadar uyumlu, dengeli ve sağlıklı olur (Çınar, Hatunoğlu ve Hatunoğlu, 2009).

Bireyin yaşamının ilk yıllarında gelişerek şekillendiği düşünülen ve diğer bireylere yönelik düşüncülerin oluşmasında bağlanma önemli bir faktördür. Bağlanma stilleri problem çözme ve iletişim becerilerinin altında yer alan değişkenlerden biri olabileceği bu nedenlerden dolayı söylenebilir 
(Bartholomew ve Horowitz, 1991). Bağlanma stili, bir kişinin bağlanma deneyimlerini, geçmişini içselleştirilmesinden kaynaklanan ilişkisel beklentilerini, ihtiyaçların, duyguların ve davranışların sistematik örüntüsünü tanımlar (Shaver ve Mikulincer, 2002). Bireylerin yaşamlarının ilk yıllarından itibaren geliştirmiş oldukları bu bağlanma stilleri bireylerin davranış şekillerinin, yetişkinlikteki sosyal iletişimin ve etkileşimin, iletişim becerilerinin, sosyal ilişkilerin üzerinde etkisi olabileceği söylenebilir (Arslan, Arslan ve Arı, 2012; Tokmak, Turgut ve Öktem, 2013). Bağlanma stilleri bireyin yaşam yolculuğunu yansıtır, ilişki deneyimlerinden kurgulanmıştır (Zhang ve Labouvie-Vief, 2004) ve bir insanın hayattaki ilişkisel yolculuğunu beşikten mezara kadar etkiler (Bowlby, 1979). Yetişkin bağlanma literatürü, bağlanma kararlılığının ve değişimin konusuna daha fazla önem verilmesinin önemini vurgulayarak, bağlayıcılığın yetişkinlik işleyişinde örgütleyici bir rol oynadığını göstermektedir (Zhang ve Labouvie-Vief, 2004). Yapılan araştırmaların sonuçlarında güvensiz bağlanma stillerine sahip bireylerin etkili iletişim becerileri sergileyemediği bu nedenlerden dolayı da sosyal yaşamlarında olumsuz davranış stilleri gerçekleştirdikleri görülmektedir (Kılıç ve Kümbetlioğlu, 2016).

Bireyde var olan bağlanma stillerinin bireyin yaşamını etkilediği bilinmektedir. İnsan doğası gereği diğer insanlarla iletişim kurma ihtiyacı hissedebilmektedir. Bireyler iletişimle karşındakilerle güçlü bağlar kurabilir. Sosyal bir varlık olan insan yaşamı boyunca pek çok insanla etkileşime girer ve bu etkileşimlerde bazen problemlerle karşılaşabilmektedir. Bu karşılaşttğ1 problemlerin çözümünde iletişim becerilerini ve problem çözme becerilerini kullanmaktadır. Problem çözme davranışlarını belirleyen etkenlerden biri de bağlanma stilleridir. İletişim becerisi problem çözme becerisinin içerisinde yer almaktadır. Buradan yola çıkarak iyi bir iletişim becerisi ile problem çözümünün de kolaylaşacağı söylenebilir. Bu araştırma ile üniversite öğrencilerinin iletişim becerileri, problem çözme becerileri ve bağlanma stilleri ve aralarındaki ilişki incelenerek literatüre katkıda bulunulanacaktır. $\mathrm{Bu}$ araştırmada ise mevcut eksiklikten yola çlkarak üniversite öğrencilerinin iletişim becerilerinin ve problem çözme becerilerinin bağlanma stillerinden ne yönde etkilendiğini belirlemek amaçlanmıştır. Bu nedenle bu araştırmada şu alt problemler cevap aranmıştır:

1. Üniversite öğrencilerinin iletişim becerileri ile problem çözme becerileri arasında anlamlı bir ilişki var mıdır? 
2. Üniversite öğrencilerinin iletişim becerileri ile bağlanma stilleri arasında anlamlı bir ilişki var mıdır?

3. Üniversite öğrencilerinin problem çözme becerileri ile bağlanma stilleri arasında anlamlı bir ilişki var mıdır?

4. Cinsiyet ile üniversite öğrencilerinin iletişim becerileri, problem çözme becerileri ve bağlanma stilleri arasında anlamlı bir ilişki var midir?

5. Yaş ile üniversite öğrencilerinin iletişim becerileri, problem çözme becerileri ve bağlanma stilleri arasında anlamlı bir ilişki var mıdır?

\section{Yöntem}

Bu araştırmada korelasyon(ilişkisel) tarama modeli kullanılmıştır. Bu model iki ve daha fazla değişkenler arasındaki değişimlerin var olup olmamasını var ise miktarını ve yönünü göstermek için kullanılmaktadır (Tekbıyık, 2014).

\section{Çalışma Grubu Ve Veri Toplama Araçları}

Araştırmanın genel evrenini üniversite öğrencileri oluşturmaktadır. Öğrenciler tesadüfi eleman örnekleme yöntemi ile Giresun (bir devlet) Üniversitesi'nin eğitim fakültesinde 2018-2019 eğitim (öğretim) yılında öğrenim görmekte olan 1., 2., 3. ve 4. sınıflarından seçilmiştir. Kişisel bilgi formu ve anketler Giresun Üniversitesi'nde öğrenim görmekte olan öğrencilere uygulanmıştır. Araştırma örneklemi 140 erkek 160 kadın öğrenci olmasıyla beraber toplamda 300 öğrenciden oluşmaktadır.

Kişisel Bilgi Formu: Katılımcıların sosyo-demografik özellikleri ve konuyla ilişkili olabileceği düşünülen bazı değişkenler hakkında bilgi toplamak amaciyla araştırmacı tarafından hazırlanan sorulardan oluşmaktadır. $\mathrm{Bu}$ formda yaş, cinsiyet, kardeş sayısı, kaçıncı çocuk oldukları, anne-baba eğitim durumu ve ailenin ekonomik düzeyi yer almaktadır.

İletişim Becerilerini Değerlendirme Ölçeği (İBDÖ): Korkut (1996) tarafından 25 maddeden oluşan hiçbir zamandan (1) her zamana (5) doğru puanlanan beşli likert tipi şeklinde hazırlanmıştır. Buradan alınabilecek en yüksek 
puan 125, en düşük puan 25'tir. Puan miktarı arttıkça ferdin iletişim kabiliyetini müspet istikamette değerlendirmektedir. Korkut ölçeğin geçerlilik ve güvenirlik çalışmalarını yapmış ve alfa iç tutarlılık katsayısı 0.80 olarak bulunmuştur (Korkut, 1996).

İlişki Ölçekleri Anketi: 1991 yılında Bartholomew ve Horowitz tarafından geliştirilen bu ölçeğin, Türkçe geçerlilik ve güvenilirlik çalışması Sümer ve Güngör (1999) tarafından yapılmıştır. Bu ölçeğin test tekrar test güvenirliliği .78 olarak belirlenmiştir (Sümer ve Güngör, 1999). 30 maddeden oluşan ölçek 7'li likert biçiminde puanlanmaktadır. Ölçeğin alt boyutlarında güvenli bağlanma, korkulu bağlanma, saplantılı bağlanma ve kayıtsız bağlanma tarzları yer almaktadır (Karaşar, 2014). Bu alt ölçeklerden güvenli bağlanma alt ölçeği, İÖA'nin 3., 7., 8., 10. ve 17. sorularından oluşur. saplantılı alt ölçek ise 5 . sorunun tersi, 6., 11. ve 15. sorularının yantları , korkulu alt ölçek 1., 4., 9. ve 14. sorularının yanıtları, kayıtsız bağlanma alt ölçeği ise 2., 5., 12., 13. ve 16. sorularınin cevapları hesaplanarak bulunur.

Problem Çözme Envanteri (PÇE): Problem Çözme Envanteri 32 maddeli likert tipi bir ölçme aracıdır. Maddelere verilen cevaplar 1 (kesinlikle katılıyorum) ile 6 (kesinlikle katılmıyorum) arasındadır (Şahin, Şahin ve Heppner, 1993). Ölçekte toplamda 35 soru yer almaktadır. 9., 22. ve 29. maddeler puanlanmayan maddelerdir. Puanlamadan alınabilecek değerler 32-192 puan aralığındadır (Korkmaz, Pancar, Alparslan ve Ayan, 2017). Ölçekten alınan puanlar arttıkça birey problem çözme becerisi yönünden kendini yetersiz görmektedir. Bu araştırmada problem çözme beceri düzeyleri "yüksek", "orta" ve "düşük" olmak üzere üç gruba ayrilmıştır. Yüksek grubunu 32-85, orta grubunu 86-129, düşük grubunu 130-192 puan aralığ1 oluşturmaktadır (Çınar, Hatunoğlu ve Hatunoğlu, 2009).

\section{Verilerin Analizi}

Araştırmadan ölçülmek istenilen verileri analiz etmek için SPSS 24.0 paketi (programı) kullanılmıştır. Verilerin analizinde yüzde, ortalama, t testi, tek yönlü varyans testi(analizi), Kruskal Wallis ve Mann Whitney U testi uygulamaları yapılmıştır.

İletişim becerilerini değerlendirme, problem çözme becerileri, bağlanma stillerinin alt boyutlarından elde edilen puanların normal dağılım gösterip 
göstermediğini belirlemek amacıyla Shapiro Wilk testi sonucunda iletişim becerilerini değerlendirme ölçeği puanlarının normal dağıldığı saptanmıştır. Problem çözme becerisi ölçeğinden alınan puanlar ile bağlanma stillerinin alt ölçeğinden alınan puanların dağılımının normal dağılmadığı saptanmıştır. İki grup arasındaki farkı incelemek için Mann Whitney U testi, ikiden fazla partametrik dağılan grupların arasındaki karşılaştırmalarda Kruskal Wallis $\mathrm{H}$ testi kullanılmıştır. Kruskal Wallis $\mathrm{H}$ testi sonucunda manidar çıkan farkları hangi gruplar arasında manidar olduğunu belirlemek için Mann Whitney U testi yapılmıştır.

\section{Bulgular}

$\mathrm{Bu}$ bölümde demografik verilerin analizi yapıldıktan sonra araştırmanın esas gayesi olan öğrencilerin iletişim becerileri, problem çözme becerileri ve bağlanma stilleri arasındaki ilişki test edilmiştir. Öğrencilerin iletişim becerilerini değerlendirme, problem çözme becerileri ve bağlanma stilleri ölçeklerinden aldıkları puanlar ile araştırmacı tarafından hazırlanan kişisel bilgi formundan alınan bilgiler arasındaki ilişkiler incelenip sunulmuştur.

Tablo 1. Araştırma Katılımcılarının Sosyodemografik Değişkenlere İlişkin Dağılımı

\begin{tabular}{|c|c|c|c|}
\hline Değişkenler & Grup & Say1 & Yüzde \\
\hline \multirow[t]{2}{*}{ Cinsiyet } & Kadın & 160 & $\% 53.3$ \\
\hline & Erkek & 140 & $\% 46.7$ \\
\hline \multirow{4}{*}{ Yaş } & $18-20$ yaş & 150 & $\% 50$ \\
\hline & $21-23$ yaş & 102 & $\% 34$ \\
\hline & $24-26$ yaş & 23 & \%7.7 \\
\hline & 26 üzeri yaş & 25 & $\% 8.3$ \\
\hline \multirow{6}{*}{ Kardeş sayısı } & Tek çocuk & 12 & $\% 4$ \\
\hline & 2 kardeş & 60 & $\% 20$ \\
\hline & 3 kardeş & 81 & $\% 27$ \\
\hline & 4 kardeş & 67 & $\% 22.3$ \\
\hline & 5 kardeş & 36 & $\% 12.0$ \\
\hline & 6 kardeş ve üzeri & 44 & $\% 14.7$ \\
\hline \multirow{3}{*}{ Doğum sırası } & İlk çocuk & 101 & $\% 33.7$ \\
\hline & Ortanca çocuk & 94 & $\% 31.3$ \\
\hline & Son çocuk & 102 & $\% 34$ \\
\hline \multirow{6}{*}{ Anne eğitim } & Okur-yazar değil & 43 & \%14.3 \\
\hline & Okur-yazar & 21 & $\% 7$ \\
\hline & İlkokul & 145 & $\% 48.3$ \\
\hline & Ortaokul & 48 & $\% 16$ \\
\hline & Lise & 30 & $\% 10$ \\
\hline & Üniversite & 13 & $\% 4.3$ \\
\hline
\end{tabular}




\begin{tabular}{llll}
\hline \multirow{3}{*}{ Baba eğitim } & Okur-yazar değil & 8 & $\% 2.7$ \\
\cline { 2 - 4 } & Okur-yazar & 15 & $\% 5$ \\
\cline { 2 - 4 } & İlkokul & 116 & $\% 38.7$ \\
\cline { 2 - 4 } & Ortaokul & 47 & $\% 15.7$ \\
\cline { 2 - 4 } & Lise & 54 & $\% 18$ \\
\cline { 2 - 4 } & Üniversite & 60 & $\% 20$ \\
\hline Ekonomik durumu & Yüksek & 1 & $\% 0.3$ \\
\cline { 2 - 4 } & Orta & 265 & $\% 11.3$ \\
\cline { 2 - 4 } & Düşük & 34 & \\
\hline
\end{tabular}

Tablo 1 incelendiğinde araştırmaya katılan öğrencilerin 160'ının (\%53.3) kadınlardan oluştuğu ve 140'inın (\%46.7) erkeklerden oluştuğu, 18-20 (\%50) yaş aralığında olduğu görülmüştür. Araştırmaya katılan öğrencilerin 81'i (\%27) 3 kardeş, 102' si (\%34) son çocuk, 145'inin (\%48.3) annesi ilkokul mezunu, 116'sinın (\%38.7) babası ilkokul mezunu ve 265'inin (\%88.3) ekonomik durumunun orta gelirli olduğu söylenebilir.

Tablo 2. Üniversite Öğrencilerinin İletişim, Problem Çözme Becerilerine ve Bağlanma Stilleri Alt Ölçeğine İlişkin Puan Ortalamalarn

\begin{tabular}{llllll}
\hline Değişken & $\mathrm{N}$ & @ & SS. & Min. & Max. \\
\hline İletişim & 300 & 96.29 & 11.28 & 54 & 120 \\
\hline Problem Çözme & 300 & 97.37 & 18.007 & 47 & 164 \\
\hline Güvenli Bağlanma & 300 & 20.63 & 4.21 & 6 & 35 \\
\hline Korkulu Bağlanma & 300 & 15.26 & 4.32 & 5 & 28 \\
\hline Saplantılı Bağlanma & 300 & 14.22 & 4.03 & 5 & 30 \\
\hline Kayıtsız Bağlanma & 300 & 22.86 & 5.18 & 9 & 35 \\
\hline
\end{tabular}

Tablo 2 incelendiğinde; öğrencilerin iletişim becerilerini değerlendirme ölçeğinden aldığı puan ortalamasının $96.29 \pm 11.28$, en düşük puanın 54, en yüksek puanın 120 puan olduğu, Problem çözme envanterinden alınan puanlara baktığımızda puan ortalamasının $97.37 \pm 18.007$, en düşük puanın 47, en yüksek puanın 164 puan olduğu görülmektedir. Öğrencilerin güvenli bağlanma ölçeğinden aldıkları puanların ortalaması 20.63 \pm 4.21 , korkulu bağlanma ölçeğinden aldıkları puanların ortalaması 15.26 \pm 4.32 , saplantılı bağlanma ölçeğinden aldıkları puanların ortalaması $14.22 \pm 4.03$ ve kayıtsız bağlanma ölçeğinden aldıkları puanların ortalaması $22.86 \pm 5.18$ olarak saptanmıştır. Ortalama değerlere baktığımızda grubun iletişim becerileri düzeylerinin iyi, problem çözme becerilerinin orta düzeyde ve kayıtsız bağlanma stiline sahip olduğu söylenebilir. 
Tablo 3. Üniversite Öğrencilerinin İletişim Becerileri Ve Problem Çözme Becerileri Arasındaki Korelasyona İlişkin Bulgular

\begin{tabular}{llll}
\hline Değişken & $\mathrm{N}$ & $\mathrm{r}$ & $\mathrm{p}$ \\
\cline { 1 - 3 } İletişim Becerileri Ölçeği Puanları & 300 & -.400 & .000 \\
\cline { 1 - 3 } Problem Çözme Becerileri Envanteri Puanları & & & \\
\hline
\end{tabular}

${ }^{*} p<.05$

Tablo 3 incelendiğinde Pearson korelasyon analizi sonucunda "iletişim becerileri" ile "problem çözme becerileri" arasında istatistiksel olarak .05 manidarlık düzeyinde $(\mathrm{p}=.000)$ anlamlı bir ilişki olduğu gözükmektedir $(\mathrm{r}=$ -.400, $\mathrm{p}<$.05). Çıkan sonuçlara baktığımızda iletişim becerileri yükseldikçe karşılaşılan problemleri çözmekte kolaylaşmakta çıkarımı yapılabilir.

Tablo 4. Üniversite Öğrencilerinin İletişim Becerilerini Değerlendirme İle Bağlanma Stilleri Envanterinin Alt Ölçeklerinden Alınan Puanlarn Arasındaki İlişkinin İncelenmesi

\begin{tabular}{lllll}
\hline Değişken & Değişken & N & r & p \\
\hline Güvenli Bağlanma Ölçeği Puanları & İletşşm Becerileri Ölçeği Puanları & 300 & .130 & .066 \\
Korkulu Bağlanma Ölçeği Puanları & İletişim Becerileri Ölçeği Puanları & 300 & -.203 & $.004^{*}$ \\
Saplantılı Bağlanma Ölçeği Puanları & İletşşm Becerileri Ölçeği Puanları & 300 & -.057 & $.001^{*}$ \\
Kayıtsız Bağlanma Ölçeği Puanları & İletişim Becerileri Ölçeği Puanları & 300 & .368 & .423 \\
\hline
\end{tabular}

${ }^{*} p<.05$

Tablo 4 incelendiğinde; öğrencilerin güvenli bağlanma ve kayıtsız bağlanma ölçeklerinden aldıkları puanlar ile iletişim becerilerini değerlendirme ölçeğinden aldıkları puanlar arasında istatistiksel olarak anlamlı bir ilişki olup olmadığını belirlemek amacıyla Sperman Korelasyon Analizi yapılmış ve anlamlı bir ilişki olmadığ görülmüştür (Sırasıyla; $r=.130, p=.066$ ve $\mathrm{r}=0.363, \mathrm{p}=.423 ; \mathrm{p}>$.05).

Öğrencilerin korkulu ve saplantılı bağlanma ölçeğinden aldıkları puanlar ile iletişim becerilerini değerlendirme ölçeğinden aldıkları puanlar arasında negatif yönde anlamlı bir ilişki olduğu görülmüştür ( $p<.05)$. Öğrencilerin korkulu ve saplantılı bağlanma puanları arttıkça iletişim becerileri ölçeğinden aldıkları puanlarının düşmekte olduğu görülmüştür $(\mathrm{r}=-.203$, $\mathrm{p}=.004 ; \mathrm{p}<.05)$. 
Tablo 5. Üniversite Öğrencilerinin Problem Çözme Becerileri Envanteri İle Bağlanma Stilleri Envanterinin Alt Ölçeklerinden Alınan Puanlarn Arasındaki İlişkinin İncelenmesi

\begin{tabular}{|c|c|c|c|c|}
\hline Değişken & Değişken & $\mathrm{N}$ & $\mathrm{r}$ & $\mathrm{p}$ \\
\hline Güvenli Bağlanma & Problem Çözme Becerileri Envanteri Puanları & 300 & .620 & $.001^{*}$ \\
\hline \multicolumn{5}{|l|}{ Ölçeği Puanları } \\
\hline Korkulu Bağlanma & Problem Çözme Becerileri Envanteri Puanları & & & \\
\hline Ölçeği Puanları & & 300 & .130 & .066 \\
\hline Saplantılı Bağlanma & Problem Çözme Becerileri Envanteri Puanları & & & \\
\hline Ölçeği Puanları & & 300 & .368 & .066 \\
\hline Kayıtsız Bağlanma & Problem Çözme Becerileri Envanteri Puanları & & & \\
\hline Ölçeği Puanları & & 300 & .203 & $.004^{*}$ \\
\hline
\end{tabular}

${ }^{*} p<.05$

Tablo 5'te görüldüğü gibi; öğrencilerin güvenli ve kayıtsız bağlanma ölçeğinden aldıkları puanlar ile problem çözme becerileri envanterinden aldıkları puanlar arasında istatistiksel olarak anlamlı bir ilişki olup olmadığını belirlemek amacıyla Sperman Korelasyon-Analizi yapılmış ve pozitif yönde anlamlı bir ilişki olduğ görülmüştür ( $p<.01)$. Öğrencilerin güvenli ve kayıtsız bağlanma ölçeğinden aldıkları puanları arttıkça problem çözme envanterlerinden aldıkları puanların artmakta olduğu görülmüş̧tür $(r=.620, p=$ $.001 ; \mathrm{r}=.203, \mathrm{p}=.004 ; \mathrm{p}<.05)$.

Öğrencilerin saplantılı ve korkulu bağlanma ölçeğinden aldıkları puanlar ile problem çözme envanterlerinden aldıkları puanlar arasında anlamlı bir ilişki olmadığı görülmüştür ( $r=.130, p=.066 ; r=.368, p=.066 p>.05)$.

Tablo 6. Üniversite Öğrencilerinin İletişim Becerilerinin Cinsiyet Değişkenine Göre Karşılaştırılması

\begin{tabular}{|c|c|c|c|c|c|c|}
\hline Değişken & Grup & $\mathbf{N}$ & * & SS & $t$ & $p$ \\
\hline \multirow{2}{*}{ Cinsiyet } & Kadın & 160 & 95.54 & 11.53 & .416 & .678 \\
\hline & Erkek & 140 & 96 & 11.02 & & \\
\hline
\end{tabular}

$p>.05$

Tablo 6'da görüldüğü gibi öğrencilerin iletişim becerileri ile cinsiyet değişkeni arasında anlamlı bir fark olup olmadığını incelemek amacıyla bağımsız gruplar $\mathrm{t}$ testi yapılmış ve iletişim becerileri ile cinsiyet değişkeni $(\mathrm{t}=$ $.416, \mathrm{p}>$.05) arasında anlamlı bir ilişki bulunamamıştır 
Tablo 7. Üniversite Öğrencilerinin İletişim Becerilerinin Yaş Değişkenine Göre Karşılaştırilması

\begin{tabular}{|c|c|c|c|c|c|c|}
\hline Varyansın Kaynağı & $\begin{array}{l}\text { Kareler } \\
\text { Toplamı }\end{array}$ & $\mathrm{sd}$ & $\begin{array}{l}\text { Kareler } \\
\text { Ortalamas1 }\end{array}$ & $\mathrm{F}$ & $\mathrm{p}$ & Anlamlı Fark \\
\hline Gruplar Arası & 1707.034 & 3 & 569.011 & 4.630 & $.004^{*}$ & $18-20$ yaş ile \\
\hline Gruplar içi & 36380.736 & 296 & 122.908 & & & 26 üzeri yaş \\
\hline Toplam & 38087.770 & 299 & & & & grubu \\
\hline
\end{tabular}

${ }^{*} p<.05$

Tablo 7'de görüldüğü gibi öğrencilerin iletişim becerileri ile yaş değişkeni arasında anlamlı bir fark olup olmadığını belirlemek amacıyla tek yönlü varyans analizi yapılmış ve iletişim becerileri ile yaş değişkeni $(p=.004, p<$ .05 ) arasında anlamlı bir ilişki bulunmuştur. Bulunan bu fark 18-20 yaş grubu ile 26 ve üzeri yaş grubu arasındadır. Yani öğrenciler arasındaki yaş farkı açıldıkça iletişim becerileri artmaktadır denilebilir.

Tablo 8. Üniversite Öğrencilerinin Problem Çözme Becerilerinin Cinsiyet Değişkenine Göre Karşılaştırılması

\begin{tabular}{lllllll}
\hline Değişken & Grup & N & S.O. & S.T. & U & p \\
\hline Cinsiyet & Kadın & 160 & 148.80 & 23808.5 & 10928.500 & .717 \\
& Erkek & 140 & 152.44 & 21341.50 & & \\
\hline
\end{tabular}

$p>.05$

Üniversite öğrencilerinin problem çözmeye ilişkin becerilerinin cinsiyet değişkenine göre farklı olup olmadığı Mann Whitney U testi ile incelenmiştir. Tablo 8'de görüldüğü gibi üniversite öğrencilerinin problem çözme becerileri ile cinsiyet değişkeni ( $\mathrm{U}=10928.5, \mathrm{p}=.717$; $\mathrm{p}>$.05) arasında anlamlı bir farklılık bulunamamıştır.

Tablo 9. Üniversite Öğrencilerinin Problem Çözme Becerilerinin Yaş Değişkenine Göre Karşılaştırilması

\begin{tabular}{lllllll}
\hline Değişken & Grup & $\mathrm{N}$ & Sira Ortalaması & sd. & $\mathrm{X}^{2}$ & $\mathrm{p}$ \\
\hline Yaş & $18-20$ yaş & 150 & 149.40 & 3 & 1.487 & .685 \\
& $21-23$ yaş & 102 & 155.14 & & & \\
& 24-26 yaş & 23 & 156.50 & & & \\
& 26 yaş üzeri & 25 & 132.64 & & & \\
\hline
\end{tabular}

$p>.05$

Üniversite öğrencilerinin problem çözmeye ilişkin becerilerinin yaş değişkenine göre farklı olup olmadığı Kruskal Wallis H testi ile incelenmiştir. Tablo 9'da görüldüğü gibi üniversite öğrencilerinin problem çözme beceri- 
leri ile yaş değişkeni $\left(\chi^{2}=1.487, \mathrm{p}=.685 ; \mathrm{p}>.05\right)$ arasında anlamlı bir farklılık bulunamamıştır.

Tablo 10. Üniversite Öğrencilerinin Cinsiyetleri İle Bağlanma Stilleri Alt Ölçeklerinden Aldıkları Puanları Açısından Mann Whitney U Testi İle Karşılaştırılması

\begin{tabular}{lllllll}
\hline Değişken & Grup & $\mathrm{N}$ & S.O. & S.T. & $\mathrm{U}$ & $\mathrm{p}$ \\
\hline Güvenli Bağlanma Ölçeği & Kadın & $\mathbf{1 6 0}$ & $\mathbf{1 0 9 . 3 4}$ & $\mathbf{1 7 4 9 4 . 5 0}$ & $\mathbf{3 4 7 8 . 5 0}$ & $\mathbf{. 0 2 3 ^ { * }}$ \\
& Erkek & $\mathbf{1 4 0}$ & $\mathbf{1 1 4 . 2 6}$ & $\mathbf{1 3 1 3 2 . 5 0}$ & & \\
Korkulu Bağlanma Ölçeği & Kadın & 160 & 106.80 & 17088.50 & 3506.50 & $.026^{*}$ \\
& Erkek & 140 & 87.2 & 12196.50 & & \\
Saplantılı Bağlanma Ölçeği & Kadın & $\mathbf{1 6 0}$ & $\mathbf{1 0 0 . 9 9}$ & $\mathbf{1 3 7 3 5 . 0 0}$ & $\mathbf{4 2 9 6 . 0 0}$ & $\mathbf{. 8 7 2}$ \\
& Erkek & $\mathbf{1 4 0}$ & $\mathbf{9 9 . 4 5}$ & $\mathbf{1 3 9 2 3 . 0 0}$ & & \\
Kayıtsız Bağlanma Ölçeği & Kadın & 140 & 98.52 & 19021.50 & 4090.50 & .485 \\
& Erkek & 160 & 104.71 & 14660.50 & & \\
\hline
\end{tabular}

${ }^{*} p<.05$

Üniversite öğrencilerinin bağlanma stilleri alt ölçekleri ile cinsiyet değişkeni arasında anlamlı bir fark olup olmadığını incelemek için Mann Whitney U testi yapılmıştır. Tablo 10' da görüldügü gibi; güvenli bağlanma ölçeğinden alınan puanlar açısından erkek öğrencilerin lehine anlamlı bir fark vardır ( $\mathrm{U}=3478.50, \mathrm{p}=.023 ; \mathrm{p}<.05)$. Erkek öğrencilerin güvenli bağlanma puanlarının kadın öğrencilerin güvenli bağlanma puanlarına oranla daha yüksek olduğu belirlenmiştir.

Üniversite öğrencilerinin korkulu bağlanma ölçeğinden aldıkları puanlar ile cinsiyet değişkeni arasında anlamlı fark bulunmuştur. Korkulu bağlanma ölçeği puanları açısından kadın öğrencilerin aleyhine anlamlı bir fark vardır ( $\mathrm{U}=3506.50, \mathrm{p}=.024 ; \mathrm{p}<$.05). Kadın öğrencilerin korkulu bağlanma puanlarının erkek öğrencilerin korkulu bağlanma puanlarına oranla daha yüksek olduğu belirlenmiştir.

Üniversite öğrencilerinin saplantılı ve kayıtsız ölçeklerinin puanları ile cinsiyet değişkeni arasında anlamlı bir farklılık olmadığı bulunmuştur (Sırasiyla; $\mathrm{U}=4285.00, \mathrm{p}=.860$ ve $\mathrm{U}=4082.50, \mathrm{p}=.479 ; \mathrm{p}>.05$ ).

Tablo 11. Üniversite Öğrencilerinin Yaşları İle Bağlanma Stilleri Alt Ölçeklerinden Alınan Puanlan Arasındaki İlişkinin Karşılaştırılması

\begin{tabular}{lllll}
\hline Değişken & Değişken & $\mathbf{N}$ & $\mathbf{r}$ & $\mathbf{p}$ \\
\hline Güvenli Bağlanma Ölçeği Puanları & Yaş & 300 & -.006 & .600 \\
Korkulu Bağlanma Ölçeği Puanları & Yaş & 300 & -.054 & .170 \\
Saplantılı Bağlanma Ölçeği Puanları & Yaş & 300 & -.098 & .066 \\
Kayıtsız Bağlanma Ölçeği Puanları & Yaş & 300 & .114 & $.011^{*}$ \\
\hline
\end{tabular}
${ }^{*} p<.05$ 
Üniversite öğrencilerinin yaşları ile güvenli bağlanma, korkulu bağlanma ve saplantılı bağlanma ölçeklerinden aldıkları puanlar arasında istatistiksel olarak anlamlı bir ilişki olup olmadığını saptamak amacıyla Sperman Korelasyon Analizi yapılmıştır. Tablo 11'de görüldüğü gibi anlamlı bir ilişki olmadığı belirlenmiştir (Sırasıyla; $\mathrm{r}=-.006, \mathrm{p}=.600 ; \mathrm{r}=-.054, \mathrm{p}=.170$ ve $\mathrm{r}=-$ $.098, \mathrm{p}=.066 ; \mathrm{p}>$.05).

Tablo 11'de görüldüğü gibi üniversite öğrencilerinin yaşları ile kayıtsız bağlanma ölçeğinden aldıkları puanları arasında pozitif yönde anlamlı bir ilişki olduğu bulunmuştur ( $\mathrm{p}<$.05). Öğrencilerin yaşları arttıkça kayıtsız bağlanma puanlarının da artmakta olduğu saptanmıştır $(r=.114, \mathrm{p}=.011$; $\mathrm{p}<$ $.05)$.

\section{Üniversite Öğrencilerinin İletişim Becerileri İle Problem Çözme Becerileri Arasındaki İlişkiye Ait Bulgularnn Tartışma Ve Yorumu}

Araştırmanın alt problemlerinde yer alan "Üniversite öğrencilerinin iletişim becerileri ile problem çözme becerileri arasında anlamlı bir ilişki var mıdır?" sorusuna ilişkin yapılan analiz sonuçlarına göre "iletişim yetenekleri" ile "problem çözme becerileri" arasında istatistiksel olarak anlamlı bir ilişki bulunmuştur. Saracaloğlu, Yenice ve Karasakaloğlu (2009) yaptıkları çalışmada iletişim ile sorun çözme yetenekleri arasında anlamlı bir ilişki bulmuşlardır. Yapılanlar çalışmamızın sonucumuzu destekler niteliktedir. Alan yazı incelendiğinde etkili iletişim becerisinin problem çözme becerilerine olumlu yönde etki ettiği görülmüştür. Bu araştırmanın sonucuna göre üniversite öğrencilerinin iletişim beceri düzeylerinin iyi, problem çözme becerilerinin orta düzeyde olduğu görülmektedir. Bireylerin günlük yaşamda karşılaştıkları problemleri etkili iletişim becerileri kullanarak çözümleyebildiği söylenebilir. Problem çözme ve iletişim becerileri öğrenilebilir ve yaşantılar sonucunda geliştirilebilir becerilerdendir. İletişim becerileri ve problem çözme becerileri bireylerin yaşamlarını kişisel, sosyal ekonomik açıdan etkileyen önemli sosyal becerilerdendir. Bu becerilerin iyi düzeyde olması bireylerin yaşamsal doyumlarını ve yaşam kalitelerini tüm yönleriyle etkileyip artırabilir (Erözkan, 2005). Araştırma bulgularının da iletişim kabiliyetleri ve sorun çözme yeteneği arasında karşlıklı etkileşime dayandığı hipotezini desteklediği söylenebilir. 


\section{Üniversite Öğrencilerinin İletişim Becerileri İle Bağlanma Tarzlarn Arasın- daki İlişkiye Ait Bulgularn Tartışma Ve Yorumu}

Çalışmanın alt problemlerinde yer alan "Üniversite öğrencilerinin iletişim becerileri ve bağlanma tarzları arasında anlamlı bir ilişki var mıdır?" sorularına ilişkin yapılan analiz sonuçlarına göre üniversite öğrencilerinin korkulu ve saplantılı ölçeklerinden elde edilen sonuçlar ile iletişim becerilerini değerlendirme envaterinden çkan sonuçlar ile negatif yönde anlamlı bir bağ olduğu görülmüştür. Murray (2001); Murray, Rose, Bellavia, Holmes ve Kusche (2002) yapmış oldukları çalışmalarda bağlanma stilleri ve iletişim becerileri arasında anlamlı bir ilişki olduğunu belirtilmiştir. Korkulu bağlanma tarzı gösteren bireyler kendilerini ve diğerlerini değersiz görme eğilimindedirler bu nedenle bu bireyler diğer bireyler ile etkileşime girmekten kaçınırlar ve bunun sonucunda iletişim becerilerinin olumsuz etkilendiği söylenebilir. Saplantılı bağlanma stiline sahip bireyler ise kendilerini değersiz görürlerken karşısındaki bireyleri değerli görme eğilimindedir bu sebepten dolayı karşındaki kişilerden sürekli onay alma ihtiyacı hissederek ilişkileriyle sürekli meşgul olurlar bu durumların iletişim becerilerini olumsuz etkilediği söylenebilir.

\section{Üniversite Öğrencilerinin Problem Çözme Becerileri İle Bağlanma Tarzlarn Arasındaki İlişkiye Ait Bulguların Tartışma Ve Yorumu}

Araştırmanın alt problemlerinde yer alan "Üniversite öğrencilerinin problem çözme becerileri ile bağlanma stilleri arasında anlamlı bir ilişki var mıdır?" sorusuna ilişkin yapılan analiz sonucunda öğrencilerin güvenli ve kayıtsız bağlanma ölçeğinden aldıkları puanlar sorun çözme yeteneği envanterinden aldıkları puanlar arasında anlamlı ilişki olduğu görülmüştür. Öğrencilerin saplantılı ve korkulu bağlanma envanterinin sonuçlarıyla problem çözme envanterlerinden aldıkları puanlar arasında anlamsız ilişki görülmüştür. Eğeci ve Gençöz (2006) yaptıkları çalışmada güvenli bağlanma stiliyle sorun çözme arasında anlamlı bir ilişki vardır. Çıkanlar bu araştırmanın sonucunu destekler niteliktedir. Güvenli bağlanma stiline sahip bireylerin yakın çevresiyle kurdukları anlamlı ve sağlam ilişkiler sonucunda yakın çevresinden de destek alacağını bilerek karşısına çıan problem karşısında kaçmayarak, problemlere etkili çözüm yolları bulma sürecine gideceği 
söylenebilir. Kayıtsız bağlanma stiline sahip olan bireylerin ise özerkliklerine verdiği önem ile birlikte karşısına çıkan problemleri çözümleme yoluna girerek bu özerkliği devam ettirmek istedikleri için problem çözme becerilerinin gelişmiş denilebilir.

\section{Üniversite Öğrencilerinin Cinsiyeti İle İletişim Becerileri Arasındaki İlişkiye Ait Bulgularn Tartışma Ve Yorumu}

Araştırmanın alt problemlerinde yer alan "Cinsiyet ile üniversite öğrencilerinin iletişim becerileri arasında anlamlı bir ilişki var mıdır?" sorularına ilişkin yapılan analiz sonuçlarına göre kadın ve erkek öğrencilerin iletişim becerilerinde anlamlı bir ilişki bulunmamıştır. Gülbahçe (2010); Kıssal, Kaya ve Koç (2016); Koçyiğit, Koçyiğit ve Özsoy (2018); Tepeköylü-Öztürk ve Soytürk (2015) yaptıkları araştırmada kadın ve erkeler ile iletişim becerileriyle anlamlı bir ilişki bulamamışlardır. Bu yapılan çalışmaların sonucu araştırma bulguların destekler niteliktedir. Milli ve Yağcı (2017); Pelit, Karaçor ve Kılıç (2018); Sungur (2018); Turgut, Kutlu ve Mut (2018); Yılmaz, Kumcağız, Balcı-Çelik ve Eren (2011) yaptıkları çalışmada öğretmen adaylarının iletişim becerilerinin kadın öğretmen adayların lehine olduğunu bulmuşlardır bu sonuçlar araştırma bulgularını desteklememektedir.

\section{Üniversite Öğrencilerinin Cinsiyeti İle Problem Çözme Becerileri Arasındaki İlişkiye Ait Bulgularnn Tartışma Ve Yorumu}

Araştırmanın alt problemlerinde yer alan "Cinsiyet ile üniversite öğrencilerinin problem çözme becerileri arasında anlamlı bir ilişki var mıdır?" sorularına ilişkin yapılan analiz sonuçlarına göre cinsiyetler ile problem çözme becerisi arasında anlamlı bir ilişki bulunamamıştır. Kolayiş ve Turan (2018) yaptıkları çalışmada üniversite öğrencilerinin problem çözme becerisiyle kadın ve erkek gruplarda anlamlı bir ilişki yoktur. Bu çalışmalar çalışma sonucumuzu dayanak oluşturur niteliktedir. Araştırmaya katılan üniversite öğrencilerinin iletişim becerileri ve problem çözme becerileri ile cinsiyet değişkeni bakımından farklılık göstermemeleri, eğitim düzeylerinin, çoğunun ekonomik düzeyinin, anne-baba eğitim durumunun, yaşlarının birbirine yakın olması ile ilişkilendirilebilir. 


\section{Üniversite Öğrencilerinin Cinsiyeti İle Bağlanma Stilleri Arasındaki İlişkiye Ait Bulguların Tartışma Ve Yorumu}

Araştırmanın alt problemlerinde yer alan "Cinsiyet ile üniversite öğrencilerinin bağlanma stilleri arasında anlamlı bir ilişki var mıdır?" sorularına ilişkin yapılan analiz sonuçlarına göre kadın öğrenciler ile erkek öğrencilerin bağlanma stillerinin alt boyutlarında yer alan güvenli ve korkulu tarz arasında cinsiyet değişkeni ile anlamlı bir ilişki vardır. Güvenli bağlanma stili erkek öğrencilerin lehine iken, korkulu bağlanma stili kadın öğrencilerde anlamlı olarak daha yüksektir. Akbağ ve Erden-İmamoğlu (2010) yaptıkları çalışmada korkulu bağlanma stilinin kadın öğrencilerde anlamlı derecede yüksek bulurken saplantılı bağlanma stilini erkek öğrencilerde anlamlı derece de yüksek bulmuştur. Korkulu bağlanma stilli ile ilgili buldukları sonuç araştırmamızı destekler niteliktedir. Karaşar (2014) yaptı̆̆ çalışmada bağlanma stillerinin alt boyutunda yer alan güvenli bağlanma ve korkulu bağlanma stilleri ile cinsiyet değişkeni arasında anlamlı bir ilişki bulmuştur. Güvenli bağlanma stili erkeklerin lehine iken, korkulu bağlanma stili puanı kadınlarda erkeklerden istatiksel olarak anlamlı derecede daha yüksek bulunmuştur. Bu çalışmanın sonucu araştırmamızı destekler niteliktedir. Çam ve Şahin-Çelik (2018) yaptıkları çalışmada erkeklerin kayıtsız ve saplantılı bağlanma tarzlarının kadın katılımcılara göre manidar olarak yüksek olduğunu bulmuşlardır. Bağlanmanın diğer boyutlarında ise cinsiyetler arasında istatistiksel olarak anlamlı bir farklılaşma olmadığı görülmüştür. Yaptıkları çalışmanın sonucu ile bu araştırmanın sonucu örtüşmemektedir. Araştırma sonucunda çıkan korkulu bağlanma stilinin kadın öğrencilerde, güvenli bağlanma stilinin ise erkek öğrencilerde daha yüksek çımasını ataerkil bir toplum olmamıza bağlayabiliriz. Günümüzde bu yapı biraz da kırılmış olmasına rağmen kültürümüzde erkek çocukları daha atılgan, daha özgür, daha cesaretli yetiştirilmesine rağmen kız çocukları daha kontrollü, daha kurallara uyan, daha temkinli şekilde yetiştirilmesinden dolayı ortaya çıkmış olabileceği söylenebilir (Kağıtçıbaşı, 2000). 
Üniversite Öğrencilerinin Yaşı İle İletişim Becerileri Arasındaki İlişkiye Ait Bulguların Tartışma Ve Yorumu

Araştırmanın alt problemlerinde yer alan "Yaş ile üniversite öğrencilerinin iletişim becerileri arasında anlamlı bir ilişki var mıdır?" sorularına ilişkin yapılan çalışmaya göre üniversite öğrencilerin yaşı ile iletişim becerileri ile yaş değişkeni arasında anlamlı bir ilişki bulunmuştur. Bulunan bu fark 1820 yaş grubu ile 26 üzeri yaş grubu arasındadır. 26 yaş üzerindekilerin iletişim becerileri 18-20 yaş grubuna göre yüksektir. Araştırma sonucunda 26 yaş üzerinin daha yüksek iletişim beceri puanları almış olmasını geçirmiş oldukları yaşam deneyimlerinin, etkileşime girmiş oldukları birey sayılarının fazla olmasına bağlanabilir.

\section{Üniversite Öğrencilerinin Yaşı İle Problem Çözme Becerileri Arasındaki İlişkiye Ait Bulguların Tartışma Ve Yorumu}

Araştırmanın alt problemlerinde yer alan "Yaş ile üniversite öğrencilerinin problem çözme becerileri arasında anlamlı bir ilişki var mıdır?" sorularına ilişkin yapılan çalışmaya göre üniversite öğrencilerin yaşı ile problem çözme becerileri arasında anlamlı bir ilişki bulunamamıştır. Gürhan, Meriç, Kaya, Turan ve Kabataş 2018; Schreglmann ve Doğruluk (2012) yaptıkları çalışmada yaş değişkeniyle problem çözme becerileri arasında anlamlı bir ilişki bulamamışlardır. Yapılmış olan bu çalışmalar bu araştırmanın sonucunu destekler niteliktedir. Araştırmaya katılan öğrencilerin hepsinin lisans öğrencisi olması, anne- baba eğitim durumlarını, ekonomik düzeylerinin benzer olmasından dolayı bu sonuç ortaya çıkmış olabilir.

\section{Üniversite Öğrencilerinin Yaşı İle Bağlanma Stilleri Arasındaki İlişkiye Ait Bulgularm Tartışma Ve Yorumu}

Araştırmanın alt problemlerinde yer alan "Yaş ile üniversite öğrencilerinin bağlanma stilleri arasında anlamlı bir ilişki var mıdır?" sorularına ilişkin yapılan çalışmaya göre üniversite öğrencilerin yaş ile bağlanma stillerinin alt boyutunda yer alan kayıtsız bağlanma stili arasında anlamlı bir ilişki bulunmuştur. Öğrencilerin yaşı arttıkça kayıtsız bağlanma stiline sahip olma oranı da artmıştır. Şişman (2016) yılında lisans ve lisansüstü öğrencilerle 
yaptığı çalışmada bireylerin yaşlanı ile kaygılı bağlanma stili arasında açısindan anlamlı fark bulmuştur.

\section{Öneriler}

Bu sonuçlardan yola çıkıldığında şu önerilerde bulunulabilir:

1. Araştırmada üniversite öğrencilerinin iletişim becerileri, problem çözme becerileri ve bağlanma stillerine değinilmiştir. Benzer araştırmalar iletişim ve problem çözme becerilerinin geliştirilebilir beceri türlerinden olabileceği göz önüne alınarak lisans döneminden önceki yıllarda da yapilabilir.

2. Bu araştırma korelosyonel tarama modeline dayalı olarak yapılmış bir araştırmadır. Bu nedenle deney ve kontrol grubu kullanılarak bu araştırmaya benzer çalışmalar yapılabilir.

İletişim veya problem çözme becerilerinin geliştirilmesi için erken yaşlarda bireylere bu becerileri kazandıracak eğitimler verilebilir 


\title{
EXTENDED ABSTRACT
}

\section{Investigation of The Level of Grit and Happiness of Vocational High School Students}

\author{
* \\ İlknur Ezgi Koser - Yaşar Barut \\ Ondokuz Mayıs University
}

Human is a part of social structure as a social being since birth even conception. Human has been born in a suitible form for social life temperamentally.(Akkaya,2018) Communicatians has started with humanbeings. Communication is an indispensible issue throughout human existence. People has become a society thanks to communication. No matter how succesful they adopt, their quality of life and satisfaction will increase as well. (Akkaya,2018) Our interaction wit people, our connection, our boundaries are bdistinctive for our psychological and mental health. In this process, one of the skills that helps people is communication skill. First of all, a good communication skill means a good perception. The more an individual expresses himself/herself and communicates mutually ,both individuals who he/she communicates with will understand him/her in a better way and vice verse and thus good relations will be held.

During his/her life span an individual faces various problems with both in his/her life and the necessities of being a social creature. (Güçlü,2003). Changing and developing social structure, technology, political and social life, economic crises are some of the problems that individuals face (Taşç, 2005). By effectively solving these problems faced by the individual, he shows his individual success, power of being an individual and coping with the environment. One of the basic skills required for the individual to be an individual, to change his environment in the way he wants, to overcome the difficulties he encounters, to get satisfaction from his life, to feel himself sufficient and successful, and to lead a peaceful, happy and healthy life is problem solving skill (Güçlü, 2003). Problem solving skill helps individuals actively adapt to the group they belong to and the environment they live in (Mertoğlu \& Öztuna, 2004). “The more advanced an individual's problem solving skill is, the more his perception and behavior of the environment 
will be harmonious, balanced and healthy" (Çınar, Hatunoğlu \& Hatunoğlu, 2009, p. 215).

Attachment is an important factor in the formation of thoughts towards other individuals, which are thought to develop and develop in the first years of the individual's life. It can be said for these reasons that attachment styles may be one of the variables underlying problem solving and communication skills (Bartholomew and Horowitz, 1991). Attachment style defines a person's attachment experiences, relational expectations arising from the internalization of his past, systematic pattern of needs, emotions and behaviors (Shaver \& Mikulincer, 2002). It can be said that the behavior styles of individuals, social communication and interaction in adulthood, communication skills and social relations may have an effect on individuals' attachment styles that they have developed since the first years of their lives (Arslan, Arslan \& Arı, 2012; Tokmak, Turgut \& Öktem, 2013). Attachment styles reflect the individual's journey of life, constructed from relationship experiences (Zhang and Labouvie-Vief, 2004) and affect a person's relational journey in life from cradle to grave (Bowlby, 1979). Adult attachment literature shows that attachment plays an organizing role in the functioning of adulthood, emphasizing the importance of attachment stability and the importance of giving more attention to the subject of change (Zhang and Labouvie-Vief, 2004). In the results of the researches, it is seen that individuals with insecure attachment styles do not exhibit effective communication skills and therefore they perform negative behavior styles in their social lives (Kılıç \& Kümbetlioğlu, 2016).

In this study, it is aimed to determine how the communication skills and problem solving skills of university students are affected by their attachment styles based on the current deficiency.

The research sampling was defined with simple random, sample method, and the study was prepared using correlational scanning model in descriptive scanning models. This study was prepared to investigate communication skills and problem solving skills of university students on involvement styles. The research was actualized with participation of 300 undergraduate students in total (160 female and 140 male students) who have been studying at Giresun University.

On the research, personal information form as data collection tool, Communication Skills Assessment Scales (CSAS) which was developed by 
Korkut (1996) to evaluate communication skills of university students, Problem Solving Inventory which was adapted to Turkish by Şahin and Heppner to evaluate problem solving skills, Correlation Scales Survey which was adapted to Turkish by Sümer and Güngör (1999) and developed by Griggin and Bartholomew (1994) to state involvement styles were utilized.

On statical analysis of data, Mann Whitney $\mathrm{U}$ test for comparison of quantitative data in case of two groups and Kruskal Wallis $\mathrm{H}$ test for intergroup comparison of parameters in case of more than 2 groups were utilized.

As a result of Kruskal Wallis $\mathrm{H}$ test, Mann Whitney U test was made to define that significant differences are significant between which groups. The correlation between dependent and independent variables was tested by Spearman correlation analysis. As a result of research, a significant correlation has obtained between communication skills and problem solving skills. A negative significant correlation has obtained with apprehensive and obsessive involvement styles which exist on lower dimension of communication skills and involvement styles. A significant correlation has obtained with safe and apathetic involvement style which exist on lower dimension of problem solving skills and involvement styles. When the correlation between communication skills, problem solving skills and involvement skills with gender of university students has observed, a significant correlation has not obtained between communication skills and problem solving skills with gender. A significant correlation has obtained between safe and apprehensive involvement styles which exist on lower dimensions between involvement styles with gender. Apprehensive involvement style has detected in higher levels for female students whereas safe involvement style has detected in higher level for male students. When the correlation between communication skills, problem solving skills and involvement styles with ages has observed, a significant correlation has obtained between ages and communication skills. It has determined that communication skills points of aged 26 years and older are higher than aged group of 18-20 years. A significant difference could not be obtained between ages and problem solving skills. When the correlation between ages and involvement styles has observed, a significant correlation has obtained with apathetic involvement style which exists on lower dimension of involvement styles. Apathetic involvement styles of students have also increased while their ages were increasing. 


\section{Kaynakça / References}

Akbağ, M. ve Erden-İmamoğlu, S. (2010). Cinsiyet ve bağlanma stillerinin utanç, suçluluk ve yalnızlık duygularını yordama gücünün araştırılması. Kuram ve Uygulamada Eğitim Bilimleri, 10(2), 651-682.

Akkaya, M. A. (2018). Önce insan, önce iletişim: Bilgi ve belge yöneticileri için halkla ilişkiler. Türk Kütüphaneciliği, 32(1), 59-61. Erişim adresi: http://www.tk.org.tr/index.php/TK/article/view/2911/2823

Arslan, E., Arslan, Ç. ve Arı, R. (2012). Kişilerarası problem çözme yaklaşımlarının, bağlanma stilleri açısından incelenmesi. Kuram ve Uygulamada Eğitim Bilimleri, 12(1), 7-23.

Bartholomew, K. ve Horowitz, L. M. (1991). Attachment styles among young adults: A test of a four-category model. Journal of Personality and Social Psychology, 61(2), 226-244.

Çam, Z. ve Şahin-Çelik, G. (2018). Üniversite öğrencilerinde bağlanma stillerinin ilişkilerle ilgili bilişsel çarpıtmaları yordama gücünün incelenmesi. Anemon Muş Alparslan Üniversitesi Sosyal Bilimler Dergisi, 6(6), 787-797.

Çınar, O., Hatunoğlu, A. ve Hatunoğlu, Y. (2009). Öğretmenlerin problem çözme becerileri. Erzincan Eğitim Fakültesi Dergisi, 11(2), 215-226. https://www.pegem.net/dosyalar/dokuman/131275-20120409115016215-226.pdf adresinden erişilmiştir.

Doğan, İ. (1998). İletişim ve yabancllaşma yazll kültürümüzde ilkler. İstanbul: Sistem Yayınclik.

Eğeci, İ. S. ve Gençöz, T. (2006). Factors associated with relationship satisfaction: Importance of communication skills. Contemporary Family Therapy, 28(3), 383-391. doi:10.1007/s10591-006-9010-2

Erözkan, A. (2005). Üniversite öğrencilerinin iletişim becerilerini etkileyen faktörler.Eğitim Bilimleri Dergisi, 22(22), 135-149. http://dergipark.gov.tr/download/article-file/1751 adresinden erişilmiştir.

Güçlü, N. (2003). Lise müdürlerinin problem çözme becerileri. Milli Eğitim Dergisi, 160, 272-300.

Gülbahçe, Ö. (2010). K. K. Eğitim Fakültesi öğrencilerinin iletişim becerilerinin incelenmesi. Beden Eğitimi ve Spor Bilimleri Dergisi, 12(2), 12-22. Erişim adresi: http://dergipark.gov.tr/download/article-file/296881 adresinden erişilmiştir. 
Gürhan, N., Meriç, M., Kaya, B., Turan, N. D. ve Kabataş, E. (2018). Tıp fakültesi ve hemşirelik öğrencilerinde intihar olasılı̆̆ı ve problem çözme becerilerinin sosyodemografik değişkenler açısından karşılaştırılması. Gümüşhane Üniversitesi Sağlik Bilimleri Dergisi, 7(1), 149-155.

Hartley, P. (2014). Kişilerarası iletişim (2. Baskı). (Ü. Doğanay, M. AktaşYamanoğlu, B. Şimşek, P. Özdemir, H. Karaaslan-Şanlı ve İ. Özdemir-Taştan, Çev.). Ankara: İmge Kitabevi.

Işık Terzi, Ş. ve Ergüner-Tekinalp, B. (2013). Psikolojik danışmada güncel kuramlar. Ankara: Pegem Akademi.

Kağıtçıbaşı, Ç. (2000). Kültürel psikoloji: Kültür bağlamında insan ve aile. İstanbul: Evrim Yayınları.

Karaşar, B. (2014). Öğretmen adaylarını bağlanma stilleri ve sosyal kaygı düzeyleri arasındaki ilişki.Amasya Üniversitesi Eğitim Fakültesi Dergisi, 3(1),27-49.

Kılıç, T. ve Kümbetlioğlu, M. (2016). Bağlanma stillerinin iletişim becerisine etkisinin araştırılması. Çukurova Üniversitesi Sosyal Bilimler Enstitüsü Dergisi, 25(3), 381-396.

Kıssal, A., Kaya, M. ve Koç, M.(2016). Hemşirelik ile beden eğitimi ve spor yüksekokulu öğrencilerinin iletişim beceri düzeyleri ve etkileyen faktörlerin değerlendirilmesi. Acıbadem Üniversitesi Sağlık Bilimleri Dergisi, 3, 134-141.

Koçyiğit, M., Koçyiğit, A. ve Özsoy, E. (2018). Kişilerarası iletişim bağlamında bireylerin iletişim becerileri ile stresle başa çıkma düzeyleri arasındaki ilişkinin incelenmesi: Milli sporcular üzerinde bir araştırma. Türk Spor Bilimleri Dergisi, 1(1), 11-19. Erişim adresi: http://dergipark.gov.tr/tsbd/issue/36533/414508

Kolayiş, H. ve Turan, H. (2018). Öğretmen adaylarının algılanan problem çözme becerileri. СВÜ Beden Ĕ̆itimi ve Spor Bilimleri Dergisi, 13(1), 22-32.

Korkmaz, N., Pancar,S., Alparslan,T. ve Ayan, A. (2017). Lise öğrencilerinin fiziksel aktivite düzeylerinin problem çözme becerilerine etkisinin incelenmesi. Sport Mont, 15(2), 15-19. http://www.sportmont.ucg.ac.me/?sekcija=article\&artid=1369 adresinden erişilmiştir.

Korkut, F. (1996). İletişim becerilerini değerlendirme ölçeğinin geliştirilmesi: güvenirlik ve geçerlik çalışmaları. Psikolojik Danışma ve Rehberlik Dergisi, 2, 18-23. 
Mertoğlu, H. ve Öztuna, A. (2004). Bireylerin teknoloji kullanımı problem çözme yetenekleri ile ilişkili midir? The Turkish Online Journal of Educational Technology, 3(1), 83-92.

Milli, M. S. ve Yağcı, U. (2017).Öğretmen adaylarının iletişim becerilerinin incelenmesi.Abant İzzet Baysal Üniversitesi Eğitim Fakültesi Dergisi,17(1),286-298.

Murray, S. L. (2001). The contingencies of interpersonal acceptance: When romantic relationships function as a self-affirmational resource? Motivation and Emotion, 25(1), 163-189. https://link.springer.com/content/pdf/10.1023/A:1010618010115.pdf adresinden erişilmiştir.

Murray, S. L., Rose, P., Bellavia, G. M., Holmes, J. G. ve Kusche, A. G. (2002). When rejection stings: How self-esteem constrains relationshipenhancement processes. Journal of Personality and Social Psychology, 83(3), 556-573. doi:10.1016/j.jrp.2017.04.0

Pelit, E., Karaçor, M. ve Kılıç, İ. (2018). Duygusal zekânın iletişim becerilerine etkisi: Turizm öğrencileri üzerinde bir araştırma. Dokuz Eylül Üniversitesi Sosyal Bilimler Enstitüsü Dergisi, 20(1), 85-107. http://dergipark.gov.tr/deusosbil/issue/36903/279686adresinden erişilmiştir. Saracaloğlu, A. S., Yenice, N. ve Karasakaloğlu, N. (2009). Öğretmen adaylarının iletişim ve problem çözme becerileri ile okuma ilgi ve alışkanlıkları arasındaki ilişki. Yüzüncü Yıl Üniversitesi Eğitim Fakültesi Dergisi, 6(2), 187-206.

Schreglmann, S. ve Doğruluk, S. (2012). Öğretmen adaylarını problem çözme becerilerinin çeşitli değişkenler açısından incelenmesi. Amasya Üniversitesi Eğitim Fakültesi Dergisi, 142), 150. http://dergipark.gov.tr/amauefd/issue/1727/21164 adresinden erişilmiştir.

Shaver, P. R. ve Mikulincer, M. (2002). Attachment-related psychodynamics. Attachment \& Human Development, 4(2), 133-161. doi:10.1080/14616730210154171

Sungur, S. A. (2018). Üniversite öğrencilerinin iletişim becerileri algisı ile kişilerarası ilişki boyutları arasındaki ilişkinin değerlendirilmesi. Selçuk Üniversitesi İletişim Fakültesi Akademik Dergisi, 11(2), 126-138.

Sümer, N. ve Güngör, D. (1999). Yetişkin bağlanma stilleri ölçeklerinin Türk örneklemi üzerinde psikometrik değerlendirmesi ve kültürlerarası bir karşlaştırma. Türk Psikoloji Dergisi, 14(43), 71-106. http://www.turkpsikolojiyazilari.com/PDF/TPD/43/05.pdf adresinden erişilmiştir. 
Şahin, N., Şahin, N. H. ve Heppner, P. P. (1993). Psychometric properties of the problem solving inventory in a group of Turkish university students. Cognitive Therapy and Research, 17(4), 379-396.

Şişman, B. (2016). İletişim becerileri ile yetişkinlerdeki bağlanma biçimlerinin psikopatoloji belirtileri arasindaki ilişkileri. Yüksek Lisans Tezi, Yükseköğretim Kurulu Ulusal Tez Merkezi veri tabanından erişildi (Tez No. 431475).

Taşçı, S. (2005). Hemşirelikte problem çözme süreci.Sağllk Bilimleri Dergisi,14,73-78. Tekbıyık, A. (2014). Kuramdan uygulamaya eğitimde bilimsel araştırma yöntemleri. Ankara: Pegem Akademi.

Tepeköylü-Öztürk, Ö. ve Soytürk, M. (2015). Beden eğitimi, müzik ve resim/görsel sanatlar öğretmenlerinin iletişim becerilerinin incelenmesi. Ahi Evran Üniversitesi Kırşehir Eğitim Fakültesi Dergisi, 16(3), 39-50.

Turgut, M., Kutlu, G. ve Mut, S. (2018). Sağlık yönetimi bölümü öğrencilerinin iletişim becerileri ile sosyal medya kullanımları arasındaki ilişkinin belirlenmesi. İsletme Bilimi Dergisi, 6(1), 185-205. Erişim adresi: http://dergipark.gov.tr/jobs/issue/36382/361049

Tokmak, İ., Turgut, H. ve Öktem, Ş. (2013). Turizm ve otelcilik öğrencilerinin sosyotropik-otonomik kişilik özelliklerinin iletişim becerilerine etkisi. Anatolia: Turizm Araştırmaları Dergisi, 24(1), 83-95.

Yılmaz, M., Kumcağız, H., Balcı-Çelik, S. ve Eren, Z. (2011). Investigating communication skill of university students with respect to early maladaptive schemas. Procedia-Social and Behavioral Sciences, 30, 968 - 972.

Zhang, F., ve Labouvie-Vief, G. (2004). Stability and fluctuation in adult attachment style over a 6-year period. Attachment \& Human Development, 6(4), 419- 437. doi:10.1080/1461673042000303127

\section{Kaynakça Bilgisi / Citation Information}

Koser, İ. E. ve Barut, Y. (2020). Üniversite öğrencilerinin iletişim becerileri, problem çözme becerileri ve bağlanma stilleri ilişkisi. OPUS-Uluslararası Toplum Araştırmaları Dergisi, 15(23), 1765-1789. DOI: 10.26466/opus.622867 